\title{
KEKUASAAN NEGARA MENURUT UUD 1945 (Analisa Kewenangan Lembaga Negara)
}

Oleh:

Sadjijono

\begin{abstract}
The division of power in the government system is an effort in cheking and balancing the interaction between agencies in the governance activity, and preventing power to be held by only one hand. Amandement of The Indonesian Constitution 1945 by Indonesia government is a step to represent the democrazy an constitution of the state, according to the constitusional system. The Amandement consists same changes to the Indonesian constitution, related to the check and balance of power. Firstly it has one agency which level is decreased from the highest agency into a high level agency.

Secondly, the amandement has several agencies to experience a reduction and a boost up of power; More ever, a new agency is being establishedi as an impact of the amandement. Due to the alteration in the constitution system, the Parliament, at present, has very limited authority. It only responsible for composing amandement of the Constitution 1945, installing the President aand Vice President, and also addressing empeachement. Ironically, with so few duties, its existence still absorb a big budget.
\end{abstract}

Keyword: Government system, power, check and balance, democracy.

\section{PENDAHULUAN}

Ditinjau dari sejarah dan perkembangan Undang-Undang Dasar yang berlaku di Negara Indonesia telah mengalami beberapa kali pergantiaan dan perubahan (amandemeri).

Pergantian yang terjadi dapat dilihat sejak UUD 1945 ditetapkan sebagai hukum dasar (grondwef) dan konsep dasar system pengelolaan kehidupan bangsa Indonesia.

Sejak kemerdekaan Indonesia tahun 1945 hingga sekarang telah terjadi empat kali pergantian dan berlaku tiga
Undang-Undang Dasar, yaitu UUD 1945 yang berlaku sejak bulan Agustus 1945 sampai dengan bulan Desember 1949; Konstitusi RIS 1949 yang berlaku mulai bulan Desember 1949 sampai dengan bulan Agustus 1950; UUDSr 1950 yang berlaku sejak bulan Agustus 1950 sampai dengan bulan Juli 1959; dan kembali ke UUD 1945 mulai bulan Juli 1959 sampai dengan sekarang, kemudian UUD 1945 telah mengalami perubahan (amandemen) empat kali.

Pergantian dan perubahan Undang -Undang Dasar tersebut, menurut M. Solly 
Lubis (M. Solly Lubis, 2002 : 2) tidak lain, adalah merupakan usaha konseptual yang didorong oleh keinginan untuk memperoleh konsep dasar pengelolaan kehidupan bangsa yang dipandang lebih sesuai dengan landasan-landasan pengelolaan dan tujuan yang akan dicapai, sehingga pergantian dan perubahan dipandang sebagai langkah untuk mencapai terwujudnya tujuan dan cita-cita negara, dan sebagai suatu usaha pemantapan ketatanegaraan untuk memperoleh suatu pemerintahan yang diharapkan akan membawa kesejahteraan bagi bangsa dan negara. Secara teoritis pergantian Undang-Undang

Dasar membawa perubahan struktur pemerintahan negara, dan kemungkinan yang lebih jauh ialah perubahan dasar filsafat negara, tujuan dan policy negara, akan tetapi di dalam praktek ketatanegaraan di Indonesia, pergantian tersebut tidak membawa perubahan dasar filsafat dan tujuan negara, hanya terbatas pada struktur dan policy negara saja, karena filsafat negara tetap Pancasila dan tujuan negara tetap sebagaimana tercantum dalam Pembukaan UUD'45. (M. Solly Lubis, 1993: 19)
Perubahan struktur yang terjadi dapat dilihat pada awal berlakunya UUD 1945 yang pada waktu itu Negara Republik Indonesia menganut system pemerintahan Presidensial dan Negara berbentuk Republik Kesatuan, kemudian atas tekanan dan pengaruh Belanda, bentuk negara berubah menjadi Negara Federal dan UUD 1945 diganti dengan Konstitusi RIS 1949 dengan system pemerintahan Parlementer. Oleh karena cita-cita bangsa Indonesia adalah membentuk negara Kesatuan, maka tidak lama kemudian negara-negara bagian Republik Indonesia Serikat sepakat untuk kembali ke Negara Kesatuan, maka Konstitusi RIS 1949 diganti dengan UUDS 1950, akan tetapi system pemerintahan tetap menganut system parlementer. Kemudian keluar Dekrit Presiden tangal 5 Juli 1959 yang salah satu subtansinya kembali ke UUD 1945.

Dengan demikian secara otomatis system pemerintahan kembali pada system presidensiil dan bentuk negara menjadi Negara Republik Kesatuan.

Selain pergantian Undang-Undang Dasar sebagaimana disebutkan di atas, dengan keluamya Ketetapan MPR RI Nomor: LX/MPR/1999 dan Ketetapan MPR 
RI Nomor: DC/MPR/2000, UUD 1945 mengalami beberapa kali perubahan (amandemen), yakni perubahan I, II, III dan ke-IV. Perubahan (amandemen) yang terjadi sebagai upaya untuk menyesuaikan perkembangan struktur kenegaraan, visi dan misi negara, karena UUD 1945 dinilai sudah tidak akomodatif dihadapkan pada perkembangan tersebut, sehingga perubahan yang terjadi sebagai tindakan demi kepentingan Negara Kesatuan Republik Indonesia untuk kurun waktu ke depan yang dapat mengakomodir segala kepentingan negara dan warganegara yang berkaitan dengan idiologi, politik, ekonomi, sosial, budaya, agama maupun pertahanan keamanan negara (Ipoleksosbudag Hankam).

Argumentasi lain dilaksanakannya amandemen (perubahan), karena UUD 1945 bersifat kesementaraan dan belum pernah ditetapkan, dan mated muatan UUD 1945 mempunyai beberapa kelemahan, antara lain: (A. Mukti Arsyad, $2000: 12-14)$
a. KekuasaanPresiden besar(executive power);
b. Sistem checks and balances, tidak diatur secara tegas;

c. Ketentuan UUD'45 banyak yang tidak jelas dan multi interpretasi;

d. UUD'45 banyak memberikan atribusi kewenangan dalam ketentuan organik;

e. Kekosongan aturan hukum dalam UUD'45.

$$
\text { Perubahan UUD } 1945 \text { yang }
$$
dilakukan pada tahap I, II, III dan ke-IV membawa pengaruh yang sangat fundamental terhadap struktur ketatanegaraan Negara Republik Indonesia serta kedudukan dan wewenang lembaga tertinggi dan lembaga tinggi negara, bahkan telah merubah secara radikal bangunan system pemerintahan Indonesia.(Harian Kompas Edisi Tanggal 12 Agustus $2002: 25$, kolom 1)

Ada beberapa lembaga negara yang kehilangan fungsi dan kewenangannya, ada yang memiliki otoritas dan legitimasi semakin kuat dan ada lembaga negara yang eksistensinya dihapuskan atau terdegradasi, yakni dari lembaga tinggi negara menjadi lembaga di dalam struktur pemerintahan negara dan melahirkan lembaga baru dengan menghapuskan lembaga lama. Menurut Syamsuddin Haris, perubahan UUD 1945 tidak hanya menuntut perubahan struktur, tetapi juga perubahan kultur para elite yang 
berkuasa, (Harian Kompas Edisi Tanggal 12Agustus $2002: 26$, kolom 6) sehingga perubahan UUD 1945 yang terjadi membawa dampak terhadap system pembagian kekuasaan negara.

\section{Kekuasaaan Negara berdasarkan Perubahan UUD 1945}

Setelah UUD 1945 dilakukan suatu perubahan, struktur ketatanegaraan negara Republik Indonesia mengalami perubahan yang sangat radikal. Perubahan dimaksud dapat dicermati dari susunan dan jenis lembaga yang ada, kewenangan, dan pembagian kekuasaannya. Sebelum terjadinya perubahan UUD 1945, struktur ketatanegaraan Indonesia menempatkan lembaga Majelis Permusyawaratan Rakyat (MPR) sebagai lembaga tertinggi negara yang berada di atas lembaga tinggi negara yang lain. Lembaga tinggi yang ada, yakni DPR, Presiden, BPK, DPA dan MA, akan tetapi setelah dilakukan perubahan MPR tidak lagi menjadi lembaga tertinggi negara dan ada lembaga tinggi negara lain yang dihapuskan, yakni Dewan Pertimbangan Agung (DPA). Selain itu muncul lembagalembaga baru seperti Dewan Perwakilan
Daerah (DPD), Mahkamah Konstitusi (MK), dan Komisi Yudicial (KY). Dengan demikian struktur ketatanegaraan berdasarkan perubahan UUD 1945 dimaksud terdiri dari lembaga MPR, DPR dan DPD sebagai kelompok kekuasaan legislative, Presiden dan Wakil Presiden memegang kekuasaan eksekutif, Mahkamah Agung (MA) dan Mahkamah Konstitusi (MK) memegang kekuasaan yudisiil, dan Badan Pengawas Keuangan (BPK) sebagai pemegang kekuasaan pengawas keuangan negara. Lembaga Komisi Yudisiil (KY) sebagai lembaga baru dilingkungan kekuasaan kehakiman yang memegang fungsi pengawasan (control), akan tetapi tidak masuk pada kekuasaan yudisiil.

\section{a. Kekuasaan Majelis Permusyawaratan Rakyat (MPR).}

Di dalam Perubahan UUD 1945 komposisi keanggotan Majelis Permusyawaratan Rakyat (MPR) mengalami perubahan, yang sebelumnya anggota Majelis Permusyawaratan Rakyat (MPR) terdiri dari anggota DPR ditambah dengan utusan-utusan dari daerah-daerah dan golongan-golongan menurut aturan yang ditetapkan dengan undang-undang, 
kemudian setelah dilakukan Perubahan ke-IV keanggotaan MPR berubah yang terdiri dari angggota Dewan Perwakilan Rakyat (DPR) dan anggota Dewan Perwakilan Daerah (DPD) yang dipilih melalui Pemilian Umum dan diatur dalam undang-undang. Perubahan keanggotaan MPR dimaksud, bukan berarti merubah system majelis perundangundangan tunggal (unicameral) menjadi system kembar (bicameral).

Di dalam system unicameral dimaksud keanggotaannya terdiri dari DPR, utusan daerah dan golongan, dan setelah perubahan keanggotaan MPR terdiri atas anggota DPR dan anggota DPD yang bukan hanya DPR dan DPD secara kelembagaan, akan tetapi anggota DPR yang terdiri dari beberapa fraksi yang berasal dari berbagai partai politik, bukan merupakan fraksi tunggal sebagai satu lembaga, dan begitu juga anggota DPD. Sangat berbeda dengan Amerika (AS), di Amerika Serikat Parlemen adalah konggres yang anggotanya terdiri atas Senat dan House of Representatives. Senat tidaklah sama dengan anggota DPR yang terdiri dari fraksi-fraksi Parpol, dan House of Representatives tidak sama dengan
Dewan Perwakilan Daerah (DPD) karena DPD juga terdiri dari perwakilan partai politik yang ada di daerah. Dengan demikian anggota DPR tidak merupakan satu lembaga parpol (fraksi tunggal), akan tetapi terdiri dari beberapa partai politik (fraksi) dan DPD pun terdiri dari beberapa perwakilan partai politik (fraksi), jadi anggota MPR adalah gabungan dari anggota DPR dan anggota DPD, bukan gabungan lembaga DPR dan lembaga DPD (vide: pasal 2 ayat (1) UUD 1945), sehingga system majelis setelah perubahan UUD 1945 tersebut belum dapat dikatakan sebagai system kembar (bicameral).

Berkaitan dengan kewenangan lembaga MPR setelah perubahan UUD 1945 juga mengalami perubahan yang mendasar, antara lain: merubah dan menetapkan Undang-Undang Dasar dan GBHN; Melantik Presiden dan/atau Wakil Presiden, yang sebelum amandemen berwenang memilih Presiden dan Wakil Presiden (vide: pasal 6 UUD 1945); dapat memberhentikan Presiden dan/atau Wakil Presiden dalam masa jabatannya menurut undang-undang dan bersidang sedikitnya sekali dalam lima tahun. Dalam hal Presiden dan/atau Wakil Presiden terbukti 
rnelakukan pelanggaran hukum seperti pengkhianatan terhadap negara, korupsi, penyuapan, perbuatan pidana berat lainnya atau tercela, atau terbukti tidak lagi memenuhi syarat sebagai Presiden dan/atau Wakil Presiden atas dasar Keputusan Mahkamah Konstitusi (MK), maka

Lembaga MPR berwenang menerima usulan pemberhentian Presiden dan/atau Wakil Presdien dimaksud dari Dewan Perwakilan Rakyat (DPR) yang merapakan hasil sidang Paripurna DPR, yang selanjutaya MPR wajib menyelenggarakan sidang paripurna untuk memutuskan usul DPR dimaksud. Kewenangan yang lain, apabila terjadi kekosongan Wakil Presiden, maka selambat-lambatnya dalam waktu 60 hari Lembaga MPR harus menyelenggarakan sidang untuk memilih Wakil Presiden.

Hubungan lembaga MPR dengan lembaga-lembaga lain yang memiliki garis langsung hanyalah dengan Presiden dan/atau Wakil Presiden, dan dengan DPR dalam rangka menerima usulan pemberhentian Presiden dan/atau Wakil Presiden yang berdasarkan keputusan Mahkamah Konstitusi (MK) dinyatakan terbukti melakukan pelanggaran hukum dan tidak memenuhi syarat lagi sebagai Presiden dan/atau Wakil Presiden, sedangkan dengan anggota DPR dan DPD terbatas pada keanggotaan dalam MPR.

Lembaga MPR yang sebelumnya memegang kedaulatan rakyat yang sepenuhnya dilaksanakan oleh MPR, akan tetapi setelah terjadinya amandemen keIV, lembaga MPR tidak lagi memegang kedaulatan rakyat dan tidak lagi sebagai lembaga tertinggi negara. Lembaga MPR menjadi lembaga negara yang tingkatannya sama dengan lembaga negara lainnya seperti Presiden, DPR, DPD, BPK, MA dan MK yang satu sama lain saling menyeimbangkan dalam mekanisme checks and balances (I Dewa Cede Palguna (Panitia Ad Hoc I Badan Pekerja MPR) yang dimuat dalam Harian Kompas Edisi Senin 12 Agustus 2002 halaman 28 Fokus, kolom 1-9) Dengan demikian setelah amandemen ke-IV UUD 1945 kewenangan MPR dapat dirinci dalam tiga hal, yakni pertama: merubah dan menetapkan UUD; kedua: melantik presiden dan/atau wakil presiden; dan ketiga: hanya dapat memberhentikan presiden dan/atau wakil presiden dalam masa jabatannya menurut UUD. Dengan demikian ada suatu pemahaman baru 
tentang paham kedaulatan rakyat berdasarkan amandemen ke-IV UUD 1945, bahwa anggota MPR yang terdiri dari anggota DPR dan anggota DPD dipilih melalui pemilihan umum.

Dari analisis di muka kewenangan Lembaga MPR dapat dibedakan sebelum dilakukan amandemen UUD 1945 dan setelah amandemen, sebagai berikut:

1) Berdasarkan komposisi keanggotaan, sebelum amandemen terdiri dari DPR, utusan daerah dan utusan golongan, dan setelah amandemen anggota MPR terdiri atas anggota DPR dan anggota DPD.

2) Sistem Rekrutmen, sebelum amandemen rekrutnien DPR lewat pemilu, dan utusan daerah, utusan golongan dengan cara diangkat; akan tetapi setelah amandemen seluruh anggota DPR dan DPD dipilih lewat pemilu.

3) Kewenangannya, sebelum amandemen tak terbatas, setelah amandemen kewenangannya terbatas pada merubah dan menetapkan UUD, melantik Presiden dan/atau Wakil Presiden, dan impeachment,

4) Kekuasaan Legislasi, sebelum amandemen oleh DPR, dan setelah amandemen kekuasaan legislasi ada di DPR dan DPD, karena DPD memiliki kewenangan mengajukan dan membahas RUU berkaitan dengan otonomi daerah.

Satu hal yang perlu dicermati, bahwa lembaga MPR tidak lagi sebagai lembaga tertinggi negara dengan tugas dan wewenang yang sangat terbatas, dimana MPR akan aktif bekerja ketika ada kegiatan merubah dan menetapkan UUD 1945, ada pelantikan Presiden dan/atau Wakil Presiden atau terjadi empeachment. Dengan demikian jika tidak ada kegiatan dimaksud keberadaan lembaga MPR menjadi vakum, sedangkan di sisi lain setiap anggota MPR menerima kesejahteraan dari negara setiap bulan, dengan jumlah anggota yang cukup besar. Pertanyaannya: Efektifkah lembaga MPR dikaitkan dengan tugas dan wewenangnya dengan kesejahteraan yang diterima? Apakah masih perlu lembaga MPR yang kewenangannya sangat terbatas, sedangkan di sisi lain ada lembaga DPR dan DPD. 


\section{b. Kekuasaan Pemerintah (Presiden} dan Wakil Presiden).

Presiden adalah lembaga eksekutif yang memegang kekuasaan peme-rintahan, yang dalam pelaksanaannya dibantu oleh Wakil Presiden. Berdasarkan amandemen ke-empat UUD 1945 pasal 6 A ayat (1) Presiden dan wakil presiden dipilih dalam satu pasangan secara langsung oleh rakyat, yang diusulkan oleh partai politik atau gabungan partai politik sebelum pelaksanaan pemilihan umum yang pelaksanaan diatur oleh Undang-undang Pemilu dan Undang-undang Pemilihan Presiden/ Wakil Presiden.

Setelah amandemen ke-IV UUD 1945 dimakud Presiden dan Wakil Presiden memiliki otoritas dan legitimasi yang sangat kuat, karena akan dipilih langsung oleh rakyat dan Presiden tidak dapat dijatuhkan oleh MPR, kedudukan MPR dengan Presiden haras check and balances. Kedudukan Presiden dan Wakil Presiden satu pasang yang sama kuatnya dengan lembaga DPR yang juga dipilih oleh rakyat. Akan tetapi kewenangan Presiden berkaitan dengan pembentukan undang-undang, yang sebelumnya memegang kekuasaan membentuk undang-undang dengan persetujuan DPR dipersempit terbatas pada mengajukan rancangan undang-undang kepada DPR sebagaimana diatur dalam pasal 5 ayat (1) UUD 1945, dan Presiden tidak dapat membekukan dan atau membubarkan DPR (vide: pasal 7 C UUD 1945).

Kekuasaan Presiden selaku kepala eksekutif, berdasarkan perubahan UUD 1945 dapat dirinci, sebagai berikut:

1) Memegang kekuasaan pemerintahan;

2) Mengajukan rancangan undangundang kepada Dewan Perwakilan Rakyat (DPR);

3) Menetapkan Peraturan Pemerintah untuk menjalankan undang-undang;

4) Memegang kekuasaan tertinggi atas Angkatan Darat (AD), Angkatan Laut $(\mathrm{AL})$, Angkatan Udara (AU);

5) Dengan persetujuan Dewan Perwakilan Rakyat (DPR) menyatakan perang, membuat perdamaian dan perjanjian dengan negara lain;

6) Mengangkat duta dan konsul dan menerima penempatan duta negara lain dengan memperhatikan pertimbangan Dewan Perwakilan Rakyat (DPR);

7) Menyatakan keadaan bahaya; 
8) Memberi grasi dan rehabilitasi dengan memperhatikan pertimbangan Mahkamah Agung (MA), dan memberi amnesti dan abolisi dengan memperhatikan pertimbangan Dewan Perwakilan Rakyat (DPR) serta memberi gelar, tanda jasa dan lain-lain tanda kehormatan;

9) Membentuk Dewan Pertimbangan;

10) Mengangkat dan memberhentikan menteri-menteri negara sebagai pembantu Presiden.

Selain kekuasaan tersebut di atas Presiden juga mempunyai kewenangan menetapkan Anggaran Pendapatan dan Belanja Negara (APBN) (staatsbegroting) atas persetujuan Dewan Perwakilan Rakyat (DPR), mengesahkan rancangan undang-undang yang telah disetujui bersama untuk menjadi undang-undang dan dalam kepentingan memaksa berhak menetapkan Peraturan Pemerintah sebagai pengganti undang-undang (Perpu), sebagaimana disebutkan dalam pasal 22 UUD 1945.

Pasal 22 dimaksud memberikan hak bagi Presiden untuk membuat Peraturan Darurat (Noodverordeningsrecht), peraturan darurat (noodverordenings) tersebut hanya boleh digunakan bila ada hal kegentingan yang memaksa (noodtoestand).

Hubungan Kekuasaan Pemerintah (Presiden) dengan Kekuasaan Kehakiman (Yudisiil), bahwa Presiden berwenang menetapkan Hakim Agung atas usulan Komisi Yudisial (KY) dan yang telah disetujui oleh Dewan Perwakilan Rakyat (DPR), mengangkat dan memberhentikan anggota Komisi Yudisial atas persetujuan Dewan Perwakilan Rakyat (DPR) dan menetapkan sembilan orang anggota Hakim Konstitusi yang diajukan oleh Mahkamah Agung (MA) tiga orang, oleh Dewan Perwakilan Rakyat (DPR) tiga orang dan oleh Presiden tiga orang.

Oleh karena Presiden sebagai penyelenggara pemerintahan (eksekutif) yang tertinggi, maka dalam menjalankan pemerintahan negara tersebut kekuasaan dan tanggungjawab ditangan Presiden (concentration of power and responsibility upon the President) ${ }^{*}$ Kekuasaan Presiden selaku Kepala Pemerintahan (eksekutif) maupun selaku Kepala Negara meskipun beberapa kekuasaan atau kewenangannya harus memperhatikan pertimbangan dan atau persetujuan DPR, akan tetapi Presiden tidak bertanggung-jawab kepada Dewan Perwakilan Rakyat (DPR) artinya 
kedudukan Presiden tidak tergantung dari Dewan Perwakilan Rakyat (DPR), walaupun kekuasaan Presiden masih dapat dikontrol atau diawasi oleh DPR, sebagaimana dirumuskan dalam pasal 20 Aayat (1) Perubahan ke-II UUD 1945.

\section{c. Kekuasaan Dewan Perwakilan Rakyat (DPR) dan Dewan Per- wakilan Daerah (DPD).}

Kekuasaan lembaga Dewan Perwakilan Rakyat (DPR) dan Dewan Perwakilan Daerah (DPD) memegang kekuasaan membentuk undang-undang (kekuasaan legislatif) yang anggotanya terdiri dari wakil-wakil rakyat yang dipilih melalui pemilihan umum. Wakil-wakil rakyat dimaksud dipilih melalui partaipartai peserta pemilu. Di samping memegang kekuasaan legislatif, lembaga DPR memiliki tiga fungsi, yakni fungsi legislasi, fungsi anggaran dan fungsi pengawasan (control). Sedangkan untuk DPD fungsi legis/atif dijalankan terbatas pada kekuasaan mengajukan rancangan undang-undang kepada DPR dan ikut membahas rancangan undang-undang yang berkaitan dengan otonomi daerah, hubungan pusat dan daerah, pembentukan dan pemekaran serta peng- gabungan daerah, pengelolaan sumber daya alam dan sumber daya ekonomi lainnya serta yang berkaitan dengan perimbangan keuangan pusat dan daerah, serta memberikan pertimbangan kepada DPR atas rancangan undang-undang APBD dan rancangan undang-undang yang berkaitan dengan pajak, pendidikan dan agama.

Fungsi pengawasan yang dimiliki Dewan Perwakilan Daerah (DPD) terbatas pada pelaksanaan undang-undang yang berkaitan dengan otonomi daerah sebagaimana tersebut di atas yang basil pengawasannya disampaikan kepada DPR untuk ditindak lanjuti.

Dengan demikian kekuasaan membentuk undang-undang yang melibatkan Dewan Perwakilan Daerah (DPD) khusus dalam pembahasan rancangan undang-undang yang berkaitan dengan otonomi daerah; hubungan pusat dan daerah; pembentukan, penggabungan dan pemekaran daerah, dan rancangan undang-undang yang berkaitan dengan pajak, pendidikan dan agama berikut pengawasan pelaksanaannya.

Di dalam menjalankan kekuasaannya tersebut, lembaga DPR mempunyai hak-hak, antara lain: hak interpelasi, hak 
angket, hak menyampaikan pendapat, dan setiap anggota DPR mempunyai hak untuk mengajukan pertanyaan, menyampaikan usul dan pendapat, hak imunitas dan hak mengajukan usul rancangan undang-undang. Hak-hak yang dimiliki oleh DPR maupun anggota DPR dimaksud tidak secara tegas dijelaskan apakah juga dimiliki oleh DPD atau anggota DPD, akan tetapi secara implisit bahwa hak-hak DPD dan anggota DPD sangatlah terbatas. Berkaitan dengan kewajibannya lembaga DPR dan DPD untuk bersidang, sedikitnya sekali dalam satu tahun.

Hubungan DPR dengan Presiden yang berkaitan dengan kekuasaan legislatif adalah DPR menyetujui rancangan undang-undang yang diajukan oleh Presiden dan menyetujui Peraturan Pemerintah serta Peraturan Pemerintah Pengganti Undang-undang (Perpu) yang diajukan oleh Presiden, dan berkaitan dengan kekuasaan eksekutif melakukan pengawasan kepada Presiden selaku kepala eksekutif dalam menjalankan pemerintahan negara. Sedangkan hubungan DPD dengan eksekutif tidak mempunyai hubungan secara langsung, kecuali pengawasan terhadap pelaksanaan undang-undang yang ber- kaitan dengan otonomi daerah, pembentukan, pemekaran dan peng-gabungan daerah, hubungan pusat dan daerah, pengelolaan sumber daya alam, dan sumber daya ekonomi lainnya, pelaksanaan anggaran pendapat dan belanja negara, pajak, pendidikan dan agama.

\section{d. Kekuasaan Kehakiman.}

\section{1) Kekuasaan Mahkamah Agung (MA).}

Kekuasaan kehakiman adalah merupakan kekuasaan yang merdeka untuk menyelenggarakan peradilan guna menegakkan hukum dan keadilan yang dipegang oleh Mahkamah Agung (MA) dan badan dibawahnya dalam lingkungan peradilan umum, peradilan agama, peradilan militer, peradilan tata usaha negara dan sebuah Mahkamah Konstitusi (vide: pasal 24 ayat (1) dan (2) UUD 1945\}.

Berdasarkan pasal 24 A Perubahan UUD'45, Mahkamah Agung (MA) sebagai sauatu lembaga negara memiliki kewenangan atau kekuasaan, untuk:

Tata-Kena Lembaga Teronggi Negara dengan'atan antax Lembaga-Lembaga Negara, pasal 11 mengenai Mahkamah Agung, dhetapkan sebagai berikut:

1) Mahkamah Agung adalah badan yang melakaukan kekuasaan 
kehakiman yang dalam pelaksanaan tugasnya, terlepas dan kekuasaan pemerintah dan pengaruh-pengaruh lainnya;

2) Mahkamah Agung dapat memberikan pertimbangan pertimbangan dalamm bidang hukum, balk diminta maupun tidak, kepada lembaga-lembaga Tinggi Negara;

3) Mahkamah Agung memberikan nasehat hukum kepada Presiden/ Kepala Negara untuk pemberian/ penolakan grasi; dan

4) Mahkamah Agung mempunyai wewenang menguji secara material hanya terhadap peraturan-peraturan perundangundangan di bawah undangundang.

\section{2) Kekuasaan Mahkamah Konstitusi (MK).}

Mahkamah Konstitusi sebagai suatu lembaga yang memegang kekuasaan kehakiman yang bertugas untuk menyelesaikan sengketa kewenangan lembaga negara yang kewenangannya diberikan oleh UndangUndang Dasar. Mahkamah Konstitusi debentuk berdasarkan Perubahan ke-III UUD 1945 dan dirumuskan dalam pasal 24 C UUD 1945, serta di atur dalam Undangundang No. 24 Tahun 2003 tentang Mahkamah Konstitusi. We-wenang Mahkamah Konstitusi berdasar-kan Perubahan ke-III UUD 1945 dan pasal 10 Undang-undang No. 24 Tahun 2003 dapat dirinci, sebagai berikut:

a) Menguji undang-undang terhadap Undang-Undang Dasar Negara RI Tahun 1945;

b) Memutuskan sengketa kewenangan lembaga Negara yang kewenangannya diberikan oleh UUD RI 1945;

c) Memutus pembabaran partai politik; dan

d) Memutus perselisihan hasil pmilihan umum.

Berkaitan dengan adanya dugaan pelanggaran hukum oleh Presiden dan/atau Wakil Presiden, maka Mahkamah Konstitusi wajib memberikan putusan atas pendapat Dewan Perwakilan Rakyat. Tugas-tugas Mahkamah Konstitusi sebelum Mahkamah tersebut dibentuk pada tanggal 17 Agustus 2003, maka segela kewenangan Mahkamah Konstitusi dilaksanakan oleh Mahkamah Agung. 
Menurut Sri Soemantri, eksistensi Mahkamah Konstitusi sebagai lembaga baru merupakan konsekuensi dari perubahan system Presidensial, karena Pressiden tidak lagi bertanggungjawab secara politik kepada Majelis Permusyawaratan Rakyat (MPR).

Mahkamah Konstitusi terdiri dari 9 hakim konstitusi yang ditetapkan oleh Presiden atas usulan dari Mahkamaah Agung (MA) 3 orang, Dewan Perwakilan Rakyat (DPR) 3 orang dan usulan Presiden 3 orang, sebagaimana dirumuskan dalam pasal $24 \mathrm{C}$ ayat (3) UUD 1945. Mensitir pendapat Jimmy Asshiddiqie, menyebutkan bahwa model Mahkamah Konstitusi dipakai terutama di negara-negara yang mengalami perubahan dari otoritarian menjadi demokrasi.

Oleh karena itu keberadaan Mahkamah Konstitusi tersebut tidak lebih untuk menyelesaikan konflik antar lembaga negara, karena dalam proses perubahan menuju negara yang demokratis tidak bisa dihindari munculnya pertentangan antar lembaga negara.

\section{3) Kekuasaan Komisi Yudisial (KY).}

Komisi Yudicial yang dibentuk berdasarkan Perubahan ke-III UUD 1945, merupakan lembaga yang baru. Berdasarkan pasal 24 B Perubahan UUD 1945 Komisi Yudisial memiliki kewenangan atau kekuasaan mengusulkan pengangkatan hakim agung, dan mempunyai wewenang lain dalam rangka menjaga dan menegakkan kehormatan, keluhuran martabat serta perilaku hakim. Eksistensi lembaga Komisi Yudisial adalah bersifat mandiri (independent) yang peran utamanya mengangkat hakim agung dan melakukan pengawasan terhadap perilaku hakim.

Keanggotaan Komisi Yudisial diangkat dan diberhentikan oleh Presiden dengan persetujuan Dewan Perwakilan Rakyat (DPR), yang susunan, kedudukan dan keanggotannya diatur dalam Undangundang No. 24 Tahun 2004 tentang Komisi Yudisial. Persyaratan anggota Komisi Yudisial harus mempunyai pengetahuan dan pengalaman dibidang hukum serta memiliki integritas dan kepribadian yang tidak tercela. Komisi Yudisial sebagai suatu lembaga baru juga mengemban fungsi inspektif terhadap hakim, akan tetapi bukan sebagai lembaga yudisiil. Tugas dan tanggungjawab Komisi Yudisial tidak lebih dari penegakan etika profesi hakim. 
Komisi Yudisial juga diberi kewenanagan mengusulkan dalam pengangkatan hakim agung, karena Komisi Yudisial sebagai lembaga inspektif lebih banyak tahu tentang kondisi hakim, sehingga hakim agung yang diangkat benar-benar memenuhi syarat moral maupun kemampuan pengetahuannya dibidang hukum.

\section{e. Kekuasaan Badan Pemeriksa Keuangan (BPK).}

Badan Pemeriksa Keuangan adalah Badan yang memeriksa pengelolaan dan tanggungjawab tentang keuangan Negara, yang dalam pelaksanaan tugasnya terlepas dari pengaruh dan kekuasaan Pemerintah, akan tetapi tidak berdiri diatas pemerintah. Tugas dan wewenang Badan Pengawas Keuangan adalah memeriksa semua pelaksanaan Anggaran Pendapatan dan Belanja Negara, yang hasil dari pemeriksaan tersebut diserahkan kepada Dewan Perwakilan Rakyat (DPR), Dewan Perwakilan Daerah (DPD), dan Dewan Perwakilan Rakyat Daerah (DPRD), yang selanjutnya ditindaklanjuti oleh lembaga perwakilan dan/atau badan sesuai dengan undang-undang.
Keanggotaan Badan Pemeriksa Keuangan dipilih oleh Dewan Perwakilan Rakyat (DPR) dengan memperhatikan pertimbangan Dewan Perwakilan Daerah. Yang berwenang untuk merismikan keangotaan Badan Pengawas Keuangan adalah Presiden.

Secara structural Badan Pengawas Keuangan berkedudukan di ibu kota negara (pusat) dan di daerah-daerah provinsi sebagai perwakilan. Dengan demikian mempunyai perwakilan secara berjenjang. Berkaitan dengan penyerahan hasil pemeriksaan, jika kita perhatikan maka bagi Badan Pengawas Keuangan di tingkat provinsi hasil pemeriksaan keuangan negara diserahkan kepada Dewan Perwakilan Rakyat Daerah (DPRD) dan kemudian untuk jenjang ke pusat diserahkan kepada Dewan Perwakilan Daerah (DPD).

\section{Analisa Kekuasaan Negara Pasca Perubahan UUD 1945.}

Kembali memperhatikan teori pembagian keknasaan yang dikeluarkan oleh Montesquieu, yang dibagi ke dalam tiga bidang legislatif, eksekutif dan yudisiil, maka baik sebelum maupun sesudah Perubahan UUD 1945, pembagian ke- 
kuasaan secara konsisten tidak dikenal dalam ketatanegaraan Indonesia. Sistem ketatanegaraan Indonesia menganut system distribusi kekuasaan, dimana kekuasaan dimaksud didistribusikan kepada lembaga-lembaga tinggi negara.

Berdasarkan UUD 1945 sebelum dilakukan perubahan, lembaga tinggi negara yang menjalankan kekuasaan negara adalah:

1) Majelis Permusyawaratan Rakyat (MPR) yang memeganag kekuasaan konstitutif atau pembuatan Undang-Undang Dasar (UUD) sebagaimana dirumuskan dalam pasal 1 ayat (2), pasal 2 dan pasal 3 UUD 1945;

2) Dewan Perwakilan Rakyat (DPR) yang memegang kekuasaan legislative atau pembuatan undangundang (pasal 19 sampai dengan pasal 22 UUD 1945);

3) Presiden, yang memegang kekuasaan eksekutif yang juga disebut pemerintah (pasal 4 sampai pasal 15UUD 1945);

4) Dewan Pertimbangan Agung (DPA), yang memegang kekuasaan konsultatif atau penasehat (pasal 16 UUD 1945);
5) Badan Pemeriksa Keuangan (BPK), yang memegang kekuasaan inspektif atau pengawasan khusus dibidang keuangan negara (pasal 23 ayat (5) UUD 1945);

6) Mahkamah Agung (MA), yang memegang kekuasaan yudikatif atau peradilan kehakiman (pasal 24 dan pasal 25 UUD 1945).

Lembaga-lembaga dimaksud mendapat kekuasaan secara atributif dari UUD 1945 untuk menjalankan negara. Menurut UUD 1945 sebelum perubahan, bahwa Majelis Permusyawaratan Rakyat (MPR) sebagai pemegang kedaulatan rakyat yang mempunyai kedudukan lebih tinggi dari lembaga-lembaga negara yang lain, sehingga Majelis Permusyawaratan Rakyat (MPR) disebut sebagai lembaga tertinggi negara.

Akan tetapi setelah terjadi Perubahan UUD 1945 ke-I,II,III dan ke-IV komponen lembaga negara dan pendistribusian kekuasaan menjadi berubah. Lembaga-lembaga Tinggi negara tersusun, sebagai berikut:

1) Majelis Permusyawaratan Rakyat (MPR), yang memegang kekuasa-an konstitutif atau meng-ubah dan menetapkan Undang-Undang Dasar 
(UUD) (pasal 3 ayat (1) Perubahan UUD'45);

2) Presiden, yang memegang kekuasaan eksekutif atau kekuasa-an pemerintahan (pasal 4 ayat (1) Perubahan UUD'45).

3) Dewan Perwakilan Rakyat (DPR) dan Dewan Perwakilan Daerah (DPD), yang memegang kekuasa-an legislatif atau kekuasaan membentuk undangundang (pasal 20 ayat (1) dan pasal 22 D Perubahan UUD'45);

4) Badan Pemeriksa Keuangan (BPK), yang memegang kekuasaan inspektif atau pengawasan tentang pengelolaan dan tanggungjawab keuangan negara (pasal $23 \mathrm{E}$ ayat (1) Perubahan UUD'45);

5) Mahkamah Agung (MA) dan Mahkamah Konstitusi (MK), yang memegang kekuasan yudisiil atau peradilan (pasal 24 ayat (2) Perubahan UUD'45).

Selain lembaga tinggi di atas, masih ada satu lembaga yang bertugas dilingkungan kekuasaan kehakiman, akan tetapi tidak masuk pada lembaga tinggi negara, yakni Komisi Yudisial (KY). Eksistensi Komisi Yudisial (KY) dan kewenangan Komisi Yudisial tersebut lebih lanjut diatur dalam Undang-undang Nomor 24 Tahun 2004 tentang Komisi Yudisial yang berwenang mengusulkan pengangkatan hakim agung dan melakukan pengawasan kepada para hakim. Komisi Yudisial (KY) ini tidak masuk dalam lembaga tinggi yang memegang kekuasaan yudikatif, karena eksistensi Komisi Yudisial terbatas untuk mengawasi dan menegakkan kode etik peradilan yang dijalankan oleh para hakim dan bersifat mandiri (independent). Selain itu Komisi Yudisial tidak menjatuhkan keputusan yang bersifat yuridis dan mengikat, karena hanya terbatas pada pelanggaran etika.

Dengan Perubahan UUD'45 tersebut, kekuasaan konstitutif yang dipegang oleh lembaga Majelis Permusyawaratan Rakyat (MPR) berubah secara radikal, sejalan dengan perubahan pasal 1 ayat (2) UUD'45 pada Perubahan ke-III, yang semula berbunyi "Kedaulatan adalah ditangan rakyat dan dilakukan sepenuhnya oleh Majelis Permusyawaratan Rakyat)", pada perubahan ke-III dirubah menjadi "Kedaulatan berada di tangan rakyat dan dilaksanakan menurut UndangUndang Dasar". 
Dengan demikian lembaga berdasarkan Undang-undang Nomor 4 Majelis Permusyawaratan Rakyat tidak Tahun 1978 juncto Undang-undang lagi melaksanakan kedaulatan rakyat, Nomor 3 Tahun 1967 tentang Dewan sehingga yang sebelumnya sebagai Pertimbangan Agung dihapuskan, lembaga tertinggi negara berabah walaupun Presiden masih harus menjadi lembaga tinggi negara yang membentuk dewan pertimbangan yang sejajar dengan lembaga-lembaga tinggi bertugas memberikan nasehat dan saran yang lain (DPR dan DPD, Presiden, MA kepada Presiden, akan tetapi dewan dan MK, dan BPK).

Sedangkan lembaga Dewan diluar lembaga tinggi negara yang setara Pertimbangan Agung (DPA) yang denganDPA.

keberadaannya dan kedudukannya

Perbedaan Struktur Ketatanegaraan Negara Republik Indonesia, sebelum dan setelah Perubahan UUD 1945 dapat digambarkan, sebagai berikut:

\section{Struktur ketatanegaraan sebelum perubahan UUD 1945}

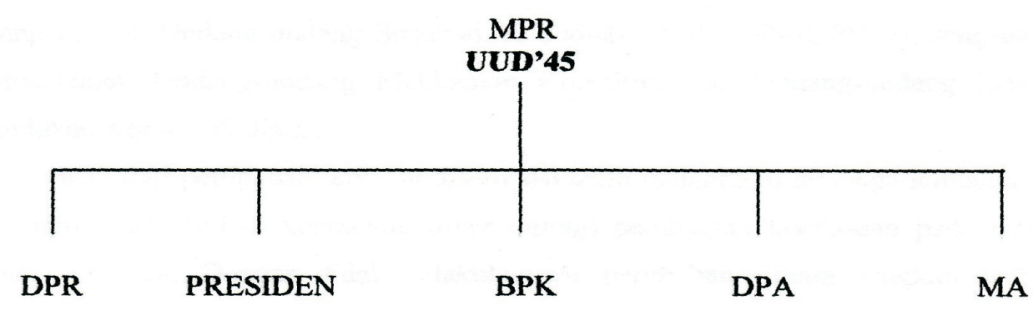

\section{Struktur ketatanegaraan setelah perubahan UUD 1945}

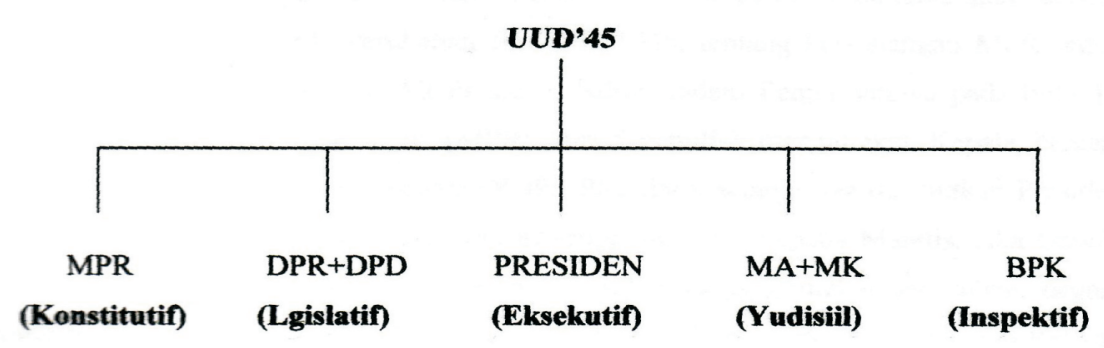


Melihat Struktur Ketatanegaraan di atas, bahwa UUD 1945 mendistribusikan kekuasaan kepada masing-masing lembaga secara check and balances, dan semua lembaga tinggi negara kedudukannya dalam posisi seimbang. Akan tetapi dengan Perubahan ke-I, ke-II, ke-III dan ke-IV UUD 1945 dimaksud kekekuasaan dari masing-masing lembaga tersebut dilaksanakan berdasar-kan undangundang.

\section{KritikTerhadap Perubahan UUD 1945.}

\section{Undang-Undang Dasar 1945} dengan perubahan ke-IV, secara tekstual telah melahirkan lembaga-lembaga demokratis baru seperti Dewan Perwakilan Daerah (DPD), Mahkamah Konstitusi (MK) dan Komisi Yudisial (KY), walaupun masih harus ditindaklanjuti dengan separangkat undang-undang yang akan menjadi aturan main lembaga tersebut. Oleh karena itu legislatif dan eksekutif harus marnpu merumuskan undang-undang yang baru secara optimal, seperti Undang-undang Pemilu, Undang-undang Parpol, Undang-undang Susunan, Kedudukan MPR/DPR/DPD, Undang-undang Kepresidenan, Undang- undang Mahkamah Konstitusi dan Undang-undang Susunan, Kedudukan Komisi Yudisial.

Hasil dari perubahan tersebut disatu sisi telah melahirkan lembagalembaga baru, disisi lain masih terjadi kerancuan (overleaping) pembagian kekuasaan pada masing-masing lembaga Dengan tidak dilakukannya perubahan secara lengkap terhadap Penjelasan Undang-undang Dasar 1945, maka esensi dari Penjelasan justru membuat kabur dan bisa terhadap kewenangan lembaga yang ada, karena banyak terdapat pasal dalam Batang Tubuh UUD 1945 telah dilakukan Perubahan, akan tetapi dalam Penjelasan tidak dirubah, sehingga bunyi dalam pasal dan penjelasannya bertentangan, seperti misalnya pasal 3 ayat (3) Perubahan III UUD 1945, tentang kewenangan MPR untuk melantik Presiden dan/atau Wakil Presiden, bahwa dalam Penjelasannya pada butir III angka 3, disebutkan Majelis ini (MPR: kursif penulis) mengangkat Kepala Negara (Presiden) dan Wakil Kepala Negara (Wakil Presiden), selanjutnya disebutkan Presiden yang diangkat oleh Majelis tunduk dan bertanggungjawab kepada Majelis. Jika 
Dewan (DPR: kursif penulis) menganggap bahwa Presiden sungguh melanggar haluan negara yang telah ditetapkan oleh Udang-Undang Dasar atau Majelis Pennusyawaratan Rakyat, maka Majelis dapat diundang untuk persidangan "istimewa" (tanda petik: kursif penulis) agar supaya bisa minta pertanggungjawaban Presiden.

Menurut Bintan Saragih, perubahan UUD 1945 masih banyak kekurangannya, sebab belum dapat mengkaji secara tepat system ketatanegaraan kemasa depan, karena masih banyak hal sebagai pelaksanaan perubahan itu yang memerlukan pengaturan dalam undangundang. Check and balances antara Presiden dan lembaga tinggi negara lainnya belum terjamin. Padahal, check and balances itu sangat vital dalam penyelenggaraan good governance. Lebih jauh Bintan Saragih dalam seminar nasional yang bertema "Perubahan UUD 1945 dan Konstruksi Sistem Ketatanegaraan Indonesia Masa depan" di Kampus Universitas Trisakti Jakarta, menanyakan dimana letak Mahkamah Konstitusi dalam system ketatanegaraan? Selain itu, dengan tidak jelasnya pembagian kewenangan antar lembaga dimaksud, juga banyak memberi ketidak pastian dan mengandung benihbenih konflik, seperti tidak diaturnya secara jelas antara Dewan Perwakilan Daerah (DPD) dengan Dewan Perwakilan Rakyat (DPR) soal pengawasan undangundang, atau antara Mahkamah Konstitusi (MK), Majelis Permusyawaratan Rakyat (MPR) dan Presiden dalam soal penetapan impeachment. Dan masih banyak lagi permasalahan-permasalahan yang ada berkaitan dengan kewenangan lembaga-lembaga tinggi negara.

Perubahan ke-IV UUD 1945 tersebut belum dapat menjamin sepenuhnya ketegasan dan kejelasan pendistribusian kekuasaan terhadap lembagalembaga tinggi negara, yakni MPR, DPR dan DPD, Presiden, MA dan MK, dan BPK secara subtantif, oleh karena itu Perubahan UUD 1945 yang telah disahkan pada tanggal 10 Agustus 2002 perlu dikoreksi kembali secara total, bahkan perlu adanya perubahan (amandemeri) lagi untuk mempertegas dan menghilangkan overleaping ke-wenangan atau kekuasaan masing-masing lembaga tinggi negara yang telah ada. 
PENUTUP.

Pasca amandemen UUD 1945 ada perbedaan dan perubahan yang mendasar terhadap kekuasaan masingmasing lembaga negara. Bahkan lembaga MPR diturunkan gradasinya dari lembaga tertinggi menjadi lambaga tinggi negara dan wewenangnya dipersempit. Tugas dan wewenang lembaga MPR antara lain meliputi merubah dan menetapkan UUD, melantik Presiden dan/atau Wakil Presiden, dan impeachemen.

Kewenangan ini sangat ensidentil dan bukan merupakan kegiatan yang dilakukan secara rutin, kecuali pelantikan Presiden dan/atau Wakil Presiden yang dilakukan setiap lima tahun sekali setelah Presiden dan/atau Wakil Presiden terpilih hasil Pemilu yang diselenggarakan. Wewenang MPR menjadi sangat terbatas dan bukan lagi sebagai lembaga perwakilam rakyat yang berdaulat. Di sisi lain DPR dan DPD diposisikan sebagai lembaga legislatif yang anggotanya terdiri dari perwakilan partai politik sebagai penjelmaan rakyat dan perwakilan daerah sebagai perubahan dari utusan golongan dan dipilih secara langsung melalui Pemilu. Eksistensi DPR dan DPD dalam lembaga legislatif belum sepenuhnya menunjukkan system parlemen negara Indonesia menganut system becameral, karena pada dasarnya DPR dan DPD memiliki kamar yang sama dan tidak memiliki suara sendiri.

Berkaitan dengan kewenangan eksekutif, dimana wewenang eksekutif menjadi lebih luas. Lahirnya lembagalembaga baru seperti Komisi Konstitusi dan Komisi Yudisiil sebagai bagian dari lembaga yang merdeka dalam menjalankan fungsi yudisiil, sebagai usaha untuk mengefektifkan eksistensi dan kemandirian lembaga Yudisiil yang diemban oleh Mahkamah Agung,

\section{DAFTAR PUSTAKA}

Abu Daud Busroh dan Abubakar Busro, Asas-Asas Hukum Tatanegara, Cet. Ketiga, Ghalia Indonesia, Jakarta, 1991

Abu Daud Busroh, ilmu negara, Bumi Aksara, Jakarta, 2001 Arbi Sanit, Sistem Politik Indonesia, Rajawali, Jakarta, 1982 Azhary, ttmu Negra Pembahasan buku Krenenburg, Ghalia Indonesia,

Jakarta,1983 Bagir Manan, Beberapa Masalah Hukum Tata Negara Indonesia, Alumni, Bandung,1997

Djoko Sutono, ttmu Negara, Ghalia Indonesia, Jakarta, 1982 Dahlan Thaib dan Mila Karmila Adi, 
Hukum dan Kekuasaan, Fakultas Hukum UII,

Yogyakarta, 1998 E. Utrecht dan Moh. Saleh Djindang, Pengantar Hukum Administrasi Negara Indonesia,

Dian Balai Pustaka Ichtiar, Jakarta, Cetakan ke-sembilan, 1990 F. Iswara, Pengantar ttmu Politik, Bina Cipta, Jakarta, Cetakan ke7,1980 Inu Kencana Syafiie, ttmu Politik, Rineka Cipta, Jakarta, 1997 Ismail Suny, Pembagian Kekuasaan Negara, Aksara Baru, Jakarta, 1985 Joen iarto, Sejarah Ketatanegaraan Republik Indonesia, Bumi Aksara, Jakarta, 1996 Kuntjoro Purbopranoto, Beberapa Catatan Hukum Tata Pemerintahan dan Peradilan

Administrasi Negara, Alumni, Bandung, 1981 M. Solly Lubis, Asas-Asas Hukum Tata Negara, Alumni, Bandung, 1987
Pembahasan UUD1945,

Alumni, Bandung, 1987

ilmu Negara, Mandar

Maju, Bandung, 1990

Mashuri Maschab, Kekuasaan Eksekutifdi Indonesia, Bina Aksara, Jakarta, 1983

M. Sastrapratedja dkk, Membatasi

Kekuasaan Telaah Mengenai Jiwa Undang-undang

Montesquieu, Gramedia Pustaka Utama, Jakarta, 1993

Miriam Budiardjo, Dasar-Dasar ttmu Politik, Gramedia Pustaka Utama, Jakarta, 2001 Moh. Kusnardi dan Harmaily Ibrahim, Pengantar Hukum Tata negara Indonesia, Pusat

Studi Hukum Tata Negara Fak. Hukum Universitas Indonesia dan Sinar Bakti, Cet. Ketujuh, Jakarta, 1988 